$\frac{10}{819188850}$

UCID- 21338

\title{
Investigation of the Fire Endurance of Borated Polyethylene Shielding Material
}

\author{
K.L. Foote
}

June 17, 1988

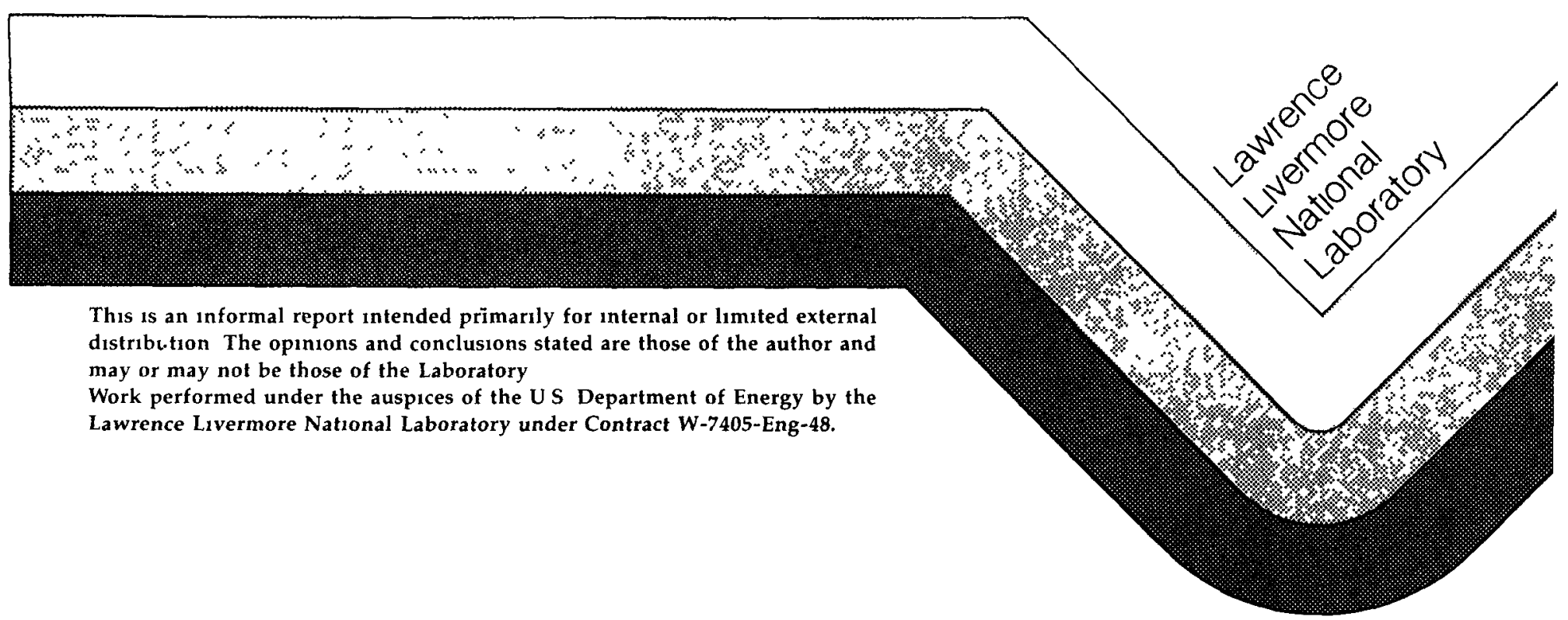




\section{DISCLAIMER}

This report was prepared as an account of work sponsored by an agency of the United States Government. Neither the United States Government nor any agency Thereof, nor any of their employees, makes any warranty, express or implied, or assumes any legal liability or responsibility for the accuracy, completeness, or usefulness of any information, apparatus, product, or process disclosed, or represents that its use would not infringe privately owned rights. Reference herein to any specific commercial product, process, or service by trade name, trademark, manufacturer, or otherwise does not necessarily constitute or imply its endorsement, recommendation, or favoring by the United States Government or any agency thereof. The views and opinions of authors expressed herein do not necessarily state or reflect those of the United States Government or any agency thereof. 


\section{DISCLAIMER}

Portions of this document may be illegible in electronic image products. Images are produced from the best available original document. 


\title{
Investigation of the Fire Endurance of Borated Polyethylene Shielding Material
}

\author{
K.L. Foote
}

UCID- -21338

DE88 014693

\begin{abstract}
We conducted nine experiments to investigate the fire endurance of a borated polyethylene shielding material to be used in the Engineering Demonstration System. Several chemistry tests were also done. The shielding material was found to melt at $93.5^{\circ} \mathrm{C}$, decompose at $230^{\circ} \mathrm{C}$, and ignite at $350^{\circ} \mathrm{C}$. Five fire tests were done in a realistic configuration and four tests in a pessimistic configuration. The material easily passed all nine tests. In each case, the shielding material never reached ignition temperature and was found acceptable in this proposed application.
\end{abstract}

\section{Introduction}

The Engineering Demonstration System (EDS) project has proposed installing a shielding material around the storage boxes inside their new glove box line. The shielding material is made of polyethylene with $0.7 \%$ boron by weight and is effective at trapping neutrons. The cost of shiclding the entire exterior of the glove box is significant, and substantial savings would result if the same amount of shielding could be placed safely inside the glove box.

Although the manufacturer claims the shielding material is non-combustible, very few materials are truly non-combustible. When a new material is used in such facilities, fire safety is always a concern. It is not necessary to have a totally non-combustible shielding material, but it is necessary to confirm that the polyethylene material would not contribute to or enhance a fire in the glove box.

A review of the manufacturer's literature revealed that the material has a density of $1.4 \mathrm{~g} / \mathrm{cm}^{3}$ and a heat of combustion of $8425 \mathrm{cal} / \mathrm{g}(35.25 \mathrm{~kW} / \mathrm{g})$. The recommended temperature limit for the material is $93^{\circ} \mathrm{C}\left(200^{\circ} \mathrm{F}\right)$. The manufacturer also claims that this material has passed the American Society for Testing and Materials (ASTM) Standard D 635-81 and ASTM Standard D 2863-77 with an Oxygen Index of 30.2. In the ASTM D 635-81 test, its average time to self-extinguish was $30.7 \mathrm{~s}$ and the average extent of burning was $6.01 \mathrm{~cm}$. The manufacturer further claims that the material "produces only negligible amounts of smoke when exposed to flame."

The ASTM tests alone are not appropriate for the fire hazard evaluation of this material. As the ASTM standard itself says "This standard ... should not be used to describe or appraise the fire hazard or fire risk of materials, products, or assemblies under actual fire conditions."1,2 Thus, additional testing would be needed to assess the polyethylene's fire worthiness.

Our preliminary tests had shown this material to be flammable. Consequently, we proposed a set of chemical analyses and exposure tests. These tests would not be truly full-scale but would reproduce the important conditions of the full-scale scenario, specifically thermal radiation from a plate of burning plutonium. It was not considered experimentally necessary and cost effective at this 
stage of the investigation to build or use a complete glove box line or storage box. The experiment would only simulate the storage box dimensions along the appropriate lines of radiation and conductivity.

The anticipated fire source is a plutonium fire burning on the top of a collector plate in the EDS glove box line. It is anticipated that the collector plate is stopped or stuck below the stainless-steel storage box. The polyethylene mounted on the outside of a stainless-steel storage box would be exposed to this potential heat source. The storage box wall is $8 \mathrm{in}$. off center of the collector plate and anywhere from 0 to $30 \mathrm{in}$. above it. ${ }^{3}$ The calculated peak radiation view factor would be at $14 \mathrm{in}$. above the collector. ${ }^{4}$ Bahowick calculated the peak surface temperatures the polyethylene would experience for various conditions. 5

with heat shield in nitrogen atmosphere

with heat shield in oxygen atmosphere

without heat shield in nitrogen atmosphere

without heat shield in oxygen atmosphere
$58^{\circ} \mathrm{C}$
$84^{\circ} \mathrm{C}$
$92^{\circ} \mathrm{C}$
$147^{\circ} \mathrm{C}$

These calculations assumed that the maximum burning surface temperature of the plutonium is $1350^{\circ} \mathrm{C}^{6}$ The exposure tests would be done to validate the above calculations and verify the safety of this material in these configurations.

\section{Chemical Analysis}

Several routine chemical analyses were done to evaluate this shielding material. A thermogravimetric analysis (TGA) revealed that it undergoes a decomposition beginning at $230^{\circ} \mathrm{C}$. It also has a $40 \%$ ash content by weight. This means that only $60 \%$ of the material volatilizes and the remainder is left as char or ash. Figure 1, a TGA plot of the heating of the material, shows this behavior. A differential scanning calorimeter (DSC) analysis revealed that the polyethylene melts at $93.5^{\circ} \mathrm{C}$, and that the decomposition occurs in two endothermic steps. These reactions require heat from an external heat source to continue. Thus, if the material melts and drops away from the heat source the decomposition will stop. Figure 2 is a DSC plot of the polyethylene decomposition showing the initial melt at $93.5^{\circ} \mathrm{C}$ and two endothermic reactions, one at $\sim 250^{\circ} \mathrm{C}$ and one at $\sim 350^{\circ} \mathrm{C}$

We observed the behavior of the polyethylene during open-air heating. We put an $11.23 \mathrm{~g}$ sample of the polyethylene in a ceramic dish and heated it slowly over a bunsen burner. A thermocouple was used to measure the temperature. The polyethylene expanded in volume as it melted and heated up."

At $230^{\circ} \mathrm{C}$ the polyethylene began to bubble. During this time the polyethylene was stirred with a glass rod in order to maintain a uniform temperature and to control the expansion of the polyethylene, which would overflow the ceramic dish. In this test the polyethylene expanded to at least four times its cold volume. Much of this was due to volatilizing gases trapped in the thick molten polyethylene. At $240^{\circ} \mathrm{C}$ the polyethylene bubbled vigorously. Above $300^{\circ} \mathrm{C}$ the polyethylene gave off white smoke. We were not able to ignite this smoke with a match.

At $350^{\circ} \mathrm{C}$ we were finally able to ignite the molten polyethylene. The surface temperature quickly rose to $425^{\circ} \mathrm{C}$. The polyethylene sustained burning in the crucible even after the burner was removed, but the flame did eventually extinguish before all of the material had decomposed. However, it was easily ignited again after stirring and reheating. We were able to continue combustion until only black and gray ashes were left. These ashes amounted to $4.57 \mathrm{~g}$, or $40.7 \%$ of the original weight of the sample. Our observations agree with the data from the TGA and DSC. In Fig. 1, a TGA plot shows that $40 \%$ of the polyethylene is non-combustible ash. In Fig. 2, we can see an endotherm at $250^{\circ} \mathrm{C}$, where the polyethylene began to boil. The final endotherm starts at $320^{\circ} \mathrm{C}$ and clearly evolves the volatile gases we ignited at $350^{\circ} \mathrm{C}$.

We compared the borated polyethylene to other polyethylene samples. Figure 3 shows DSC plots of the borated polyethylene sample, of a pure polyethylene sample, and of a generic polyethylene sample. This shows that the EDS borated polyethylene has a lower decomposition

\footnotetext{
- The coefficient of thermal expansion of the polyethylene is given by the manufacturer as $0.00018 \mathrm{~cm}^{3} / \mathrm{cm}^{3}{ }^{\circ} \mathrm{C}$. This was sufficient expansion to cause tolerance problems when removing samples after a test.
} 
temperature than either of the other polyethylenes. It fact, pure polyethylene does not ignite until it reaches $450^{\circ} \mathrm{C}$. This lower ignition temperature should be of concern if the polyethylene will be used in an area where it may be exposed to temperatures higher than $300^{\circ} \mathrm{C}$.

\section{Experiment}

These tests were designed to evaluate the effect of a worst-case plutonium fire in the EDS glove box line on a borated polyethylene shielding material. To that end, the plutonium fire is assumed to be on top of the collector, when it would be physically underneath the 0.01 -in.-thick steel top plate of the collector. The fire is assumed to burn at a uniform rate for at least two hours without dripping away from the collector or extinguishing, another extremely unlikely possibility. Two hours was judged to be more than sufficient time for us to evaluate the material. The collector is assumed to be stuck below the storage box, and thus the storage box atmosphere cannot be evacuated. The glove box line has somehow failed, and the normally inert atmosphere is ambient air which results in a $\mathrm{Pu}-\mathrm{O}_{2}$ oxidation reaction.

Since these tests were primarily to investigate the heating of the polyethylene through the stainless-steel storage box wall, only a small section of the storage box wall needed to be constructed." Figures 4 and 5 show the test setup. We were not able to obtain large 4-in.-thick pieces of polyethylene as would be used around the actual storage boxes. We were able to get a small supply of $8 \times 4 \times 2$-in. bricks. Thus, the test apparatus was designed to use these smaller bricks. An already-assembled slider device was readily available and was adapted to be used for these tests. A $12 \times 12$-in. stainless-steel plate was easily mounted to the slider. This $1 / 2$-in.-thick piece of steel would represent the storage container wall, and the polyethylene would be mounted on it, as in Fig. 4.

Each brick was cut in half to make two $4 \times 4 \times 2$-in. pieces, which were then placed together to make a $4 \times 4 \times 4$-in. block of polyethylene. This was the sample size used for all tests except Test 9 . (In Test 9 a $12 \times 6 \times 4$-in. sample was used.) A $12 \times 12 \times 4$-in. piece of Marinite was cut to surround the block of polyethylene. A $4 \times 4$-in. square was cut out of the side of the Marinite to allow the polyethylene to be fitted in, as shown in Fig. 4. Marinite was chosen to fill in for and insulate the polyethylene because it has thermal properties similar to the polyethylene (see Table 1). The use of Marinite with its superior insulation characteristics will reduce edge effects caused by using a small piece of polyethylene. Henceforth we will refer to the assembled and mounted steel plate, aluminum angle, heat shield, Marinite, and polyethylene as "the apparatus."

A slider held the apparatus firmly in place at the specified distance from the burner, as shown in Fig. 5. The burner was a premixed natural gas burner made of flat ceramic $(12 \times 6$-in.). A metal grate $1 / 4$-in. above the ceramic surface protected the burner from damage and generally glowed red during these tests. The burner was ignited and allowed to equilibrate for 20 minutes before a test was begun. We chose the temperature of the burner for these tests to be $900^{\circ} \mathrm{C}$, the bulk surface burning temperature of plutonium.6,7 After five minutes of baseline sampling, the apparatus was manually slid into its prescribed position near the burner. These tests were run for just over two hours. The data was taken at 15-s intervals by a Hewlett-Packard model 3497A data scanner and recorded on a Hewlett-Packard model 217 computer. Twenty channels of thermocouple data were recorded for each test. These tests were done in the south bay of Building 324. The bay doors were closed to reduce the effect of wind on the burner. The exhaust fans were turned to provide fresh air and to cool the bay.

Table 2 lists the conditions of the nine tests done. The first five of these tests were done in realistic orientations. The burner was positioned horizontally 5-1/2 in. from the apparatus. The last four were done in unrealistic or pessimistic orientations with the apparatus directly above the burner or with the burner positioned vertically in front of the apparatus, as in Fig. 6.

\footnotetext{
"The thermal diffusivity of a 4" thick piece of polyethylene is $9.68 \times 10^{-6} \mathrm{~m} / \mathrm{s}^{2}$. This gives a thermal penetration time of over $2600 \mathrm{~s}$. We were thus able to ignore the back side of the polyethylene and no measurements were taken there.
} 


\section{Results}

Table 3 lists the ambient temperature, average burner temperature, and the peak temperature rise observed at several locations on the exposed specimen for each test. Figure 7 shows typical temperature plots of the data. The temperature initially rises quickly, then slows as steady-state conditions are approached. The stainless-steel temperature can be seen to rise first with the aluminum and the polyethylene lagging behind. Tests 1-3 were done to validate the maximum exposure calculations and to determine the optimum vertical distance for subsequent tests. Figure 8 shows that the maximum polyethylene temperature was achieved at the 10-in. position during Test 1.

Included in the goals of these tests was to investigate the effect of the aluminum angle and heat shield. Tests 4 and 5 were done at the 10-in. horizontal position, where the steel heat shield was removed and where the aluminum angle was removed, respectively. Neither the aluminum angle or the heat shield significantly reduced the polyethylene peak temperature. As can be seen in Table 3, both tests have lower temperature rises than Test 1 . Test 5, without the aluminum angle, does have a slightly higher $\left(4^{\circ} \mathrm{C}\right)$ polyethylene temperature rise. However this may have been caused by a minor variation in the burner temperature or positioning.

Because of the benign nature of the previous tests, two tests (Tests 6 and 7) were done with the apparatus directly above the burner, which only slightly increased measured temperatures. Test 7 was 10-in. above the burner and it shows the greater temperature increase of the two tests (Table 3 ). The aluminum temperature for this test is the hottest temperature observed due to the increased view angle for radiation.

Two vertical burner tests (Tests 8 and 9) were also done. For these tests the burner was placed vertically (as in Fig. 6) directly in front of the stainless-steel plate for nearly maximum radiant exposure. These tests were valuable, in that even with this close exposure it took 30 minutes before the polyethylene reached melting temperature. It took well over an hour before we observed the polyethylene melting out the sides. Figure 9 shows the temperature of the polyethylene and the steel plate for Test 8.

The last vertical test was done without the Marinite insulation. Because of the the nondestructive nature of the previous tests, enough polyethylene remained to fill the apparatus with polyethylene and not use the Marinite insulation. For this test the apparatus was filled with nine $2 \times 4 \times 4$-in. polyethylene blocks. This test also had the closest exposure of any test: the bottom of the burner was 4 in. below the stainless-steel plate and only 5 in. away, as shown in Fig. 6. Figure 10 shows the temperature of the aluminum, the steel plate, and the polyethylene for this test. Even with this high exposure, the polyethylene did not approach its initial decomposition temperature of $230^{\circ} \mathrm{C}$ and never came close to its ignition temperature of $350^{\circ} \mathrm{C}$. After an hour the polyethylene began dripping out of the apparatus. It cooled and solidified before it dropped the $0.4 \mathrm{~m}$ to the ground. Eventually a polyethylene stalagmite formed on the ground and a polyethylene stalactite formed on the apparatus above. Toward the end of this test, the polyethylene bricks began to separate, making analysis of the temperatures difficult. However, it does not appear that this test would have given different results than a test with Marinite insulation.

\section{Conclusions}

A few qualifications should be made on the results of these tests. Our tests validate the use of this borated polyethylene shielding material only in the proposed configuration. These tests assumed that the fire/heat source is on the collector and does not account for other ignition scenarios (i.e. no trash fires or glove fires). Since we did not use a full-scale apparatus, these observations might change if a longer burner and wider stainless-steel plate was used. Also the actual storage box is enclosed and would trap any convective heat near the stainless steel wall, thus increasing the thermal exposure. Finally, Marinite is not an exact match of the polyethylene's thermal properties and it does not absorb energy as well as the polyethylene (however, this is a small difference).

Our tests showed that the borated polyethylene shiclding material is stable below $93^{\circ} \mathrm{C}$, although it does expand slightly. This expansion caused some tolerance problems during our tests. At $93^{\circ} \mathrm{C}$, the material melts and expands even more. At $230^{\circ} \mathrm{C}$ an endothermic reaction begins that 
continues until the material reaches $350^{\circ} \mathrm{C}$, at which time we were able to ignite the molten material with a match.

The borated polyethylene shielding material never got hotter than $70^{\circ} \mathrm{C}$, easily passing all five realistic tests. The shield and the aluminum angle did not make a difference in the peak temperature of the exposed polyethylene. The test without the shield and aluminum angle had a polyethylene temperature rise similar to other tests with the shield and angle. The four unrealistic tests showed that over an hour of exposure occurred before significant melting of the polyethylene shielding occurred even with nearly direct thermal exposure.

\section{References}

1. American Society for Testing and Materials, "Standard Test Method for Rate of Burning and/or Extent and Time of Burning of Self-Supporting Plastics in a Horizontal Position," American Society for Testing and Materials, Philadelphia, PA, D 635-81 (1987).

2. American Society for Testing and Materials, "Standard Method for Measuring the Minimum Oxygen Concentration to Support Candle-Like Combustion of Plastics (Oxygen Index)," American Society for Testing and Materials, Philadelphia, PA, D 2863-77 (1987).

3. Carol Caldwell, Lawrence Livermore National Laboratory, Livermore, CA, private communication, Aug. 25, 1987.

4. Leroy Holmes, Lawrence Livermore National Laboratory, Livermore, CA, private communication, Sept. 21, 1987.

5. Sally Bahowick, Lawrence Livermore National Laboratory, Livermore, CA, private communication, Oct. 1, 1987

6. R.E. Felt, "Burning and Extinguishing Characteristics of Plutonium Metal Fires," Isochem Inc., Richland, Washington, ISO-756 (1967).

7. Ronald Felt, Westinghouse Idaho Nuclear Co., Idaho Falls, ID, private communication, Oct. 1, 1987. 
Table 1. Thermal properties of borated polyethylene and Marinite insulation.

\begin{tabular}{lccccc}
\hline & $\begin{array}{c}\mathrm{k} \\
\left(\mathrm{kW} / \mathrm{m}^{\circ} \mathrm{K}\right)\end{array}$ & $\begin{array}{c}\rho \\
\left(\mathrm{kg} / \mathrm{m}^{3}\right)\end{array}$ & $\begin{array}{c}\mathrm{c} \\
\left(\mathrm{kJ} / \mathrm{kg}^{\circ} \mathrm{K}\right)\end{array}$ & $\begin{array}{c}\mathrm{kpc} \\
\left.(\mathrm{k})^{2} / \mathrm{m}^{4} \mathrm{~K}^{2} \mathrm{~s}\right)\end{array}$ & $\begin{array}{c}\alpha \\
\left(\mathrm{m}^{2} / \mathrm{s}\right)\end{array}$ \\
\hline $\begin{array}{l}\text { Polyethylene } \\
\text { Marinite }\end{array}$ & 0.00255 & 1400 & 1.883 & 6.727 & $9.68 \times 10^{-7}$ \\
& 0.00012 & 700 & 1.120 & 0.094 & $1.50 \times 10^{-7}$ \\
\hline
\end{tabular}

Table 2. Listing of all the experiments done in this series.

\begin{tabular}{cccll}
\hline Test & $\begin{array}{c}\text { Vertical } \\
\text { distance } \\
\text { (in.) }\end{array}$ & $\begin{array}{c}\text { Horizontal } \\
\text { distance } \\
\text { (in.) }\end{array}$ & Assembly & Burner \\
\hline 1 & 10 & 5.5 & Full assembly & Horizontal \\
2 & 14 & 5.5 & Full assembly & Horizontal \\
3 & 18 & 5.5 & Full assembly & Horizontal \\
4 & 10 & 5.5 & No shield & Horizontal \\
5 & 10 & 5.5 & No aluminum & Horizontal \\
& 18 & 0.0 & Full assembly & Horizontal \\
6 & 10 & 0.0 & Full assembly & Horizontal \\
7 & 4 & 5.5 & Full assembly & Vertical \\
8 & 0 & 5.5 & Polyethylene & Vertical \\
9 & & & & \\
\hline
\end{tabular}


Table 3. Summary of results.

\begin{tabular}{cccrrr}
\hline Test & $\begin{array}{c}\text { Ambient } \\
\text { a ir } \\
\text { temperature } \\
\left({ }^{\circ} \mathrm{C}\right)\end{array}$ & $\begin{array}{c}\text { Burner } \\
\text { surface } \\
\text { temperature } \\
\left({ }^{\circ} \mathrm{C}\right)\end{array}$ & $\begin{array}{r}\text { Maximum } \\
\text { steel face } \\
\text { temperature } \\
\text { rise }\left({ }^{\circ} \mathrm{C}\right)\end{array}$ & $\begin{array}{r}\text { Maximum } \\
\text { aluminum } \\
\text { temperature } \\
\text { rise }\left({ }^{\circ} \mathrm{C}\right)\end{array}$ & $\begin{array}{r}\text { Maximum } \\
\text { polyethylene } \\
\text { temperature } \\
\text { rise }\left({ }^{\circ} \mathrm{C}\right)\end{array}$ \\
& chan 17 & chan 1 & chan 4 & chan 13 & chan 15 \\
\hline 1 & 25 & 1090 & 41 & 35 & 38 \\
2 & 31 & 883 & 24 & 21 & 21 \\
3 & 28 & 978 & 19 & 17 & 16 \\
4 & 28 & 933 & 36 & 29 & 31 \\
5 & 29 & 1003 & 38 & $* *$ & 16 \\
6 & 30 & 975 & 20 & 19 & 41 \\
7 & 24 & 968 & 49 & 46 & 119 \\
8 & 31 & 878 & 116 & 88 & \\
9 & 25 & 872 & $* 131$ & 92 & \\
\hline
\end{tabular}

* Channel 7

** Aluminum not used for this test

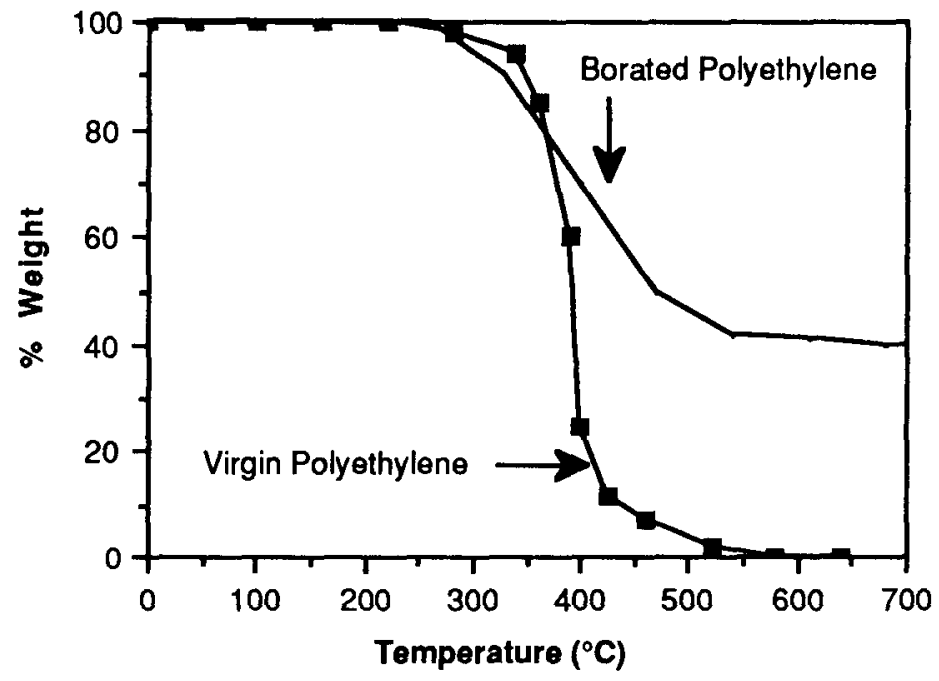

FIGURE 1. A thermogravimetric analysis plot of the decomposition of the borated polyethylene shielding material. 


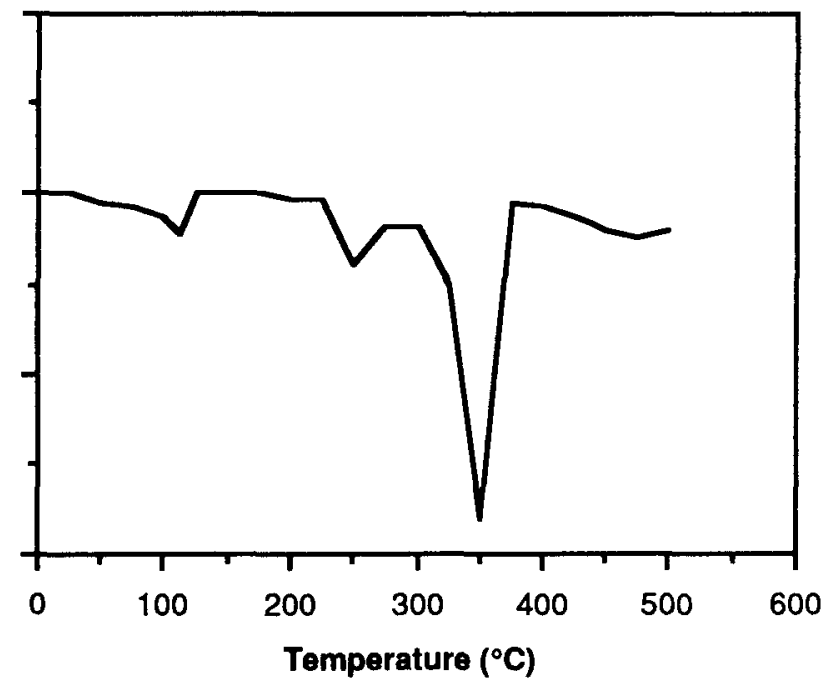

FIGURE 2. A differential scanning calorimeter plot of the decomposition of the borated polyethylene shielding material. 


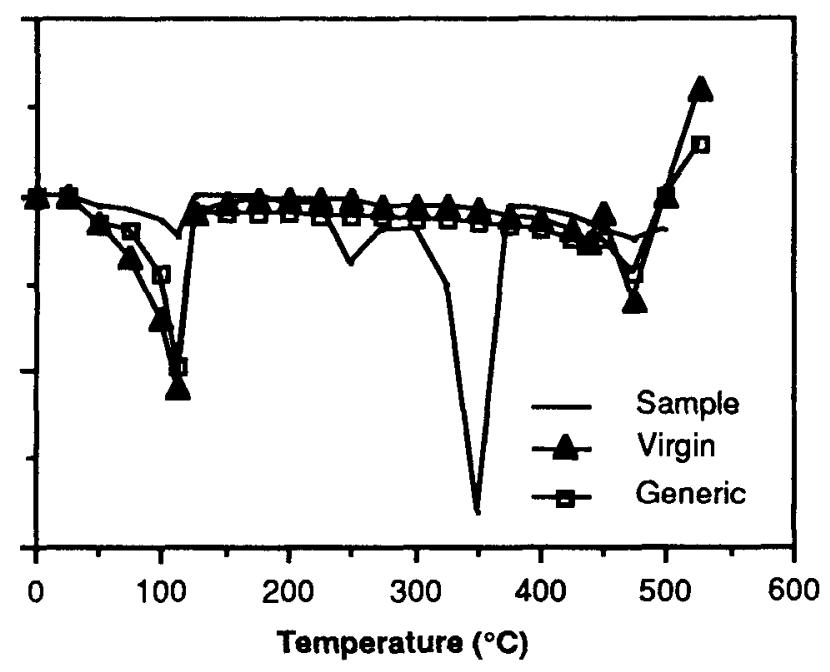

FIGURE 3. Differential scanning calorimeter plots of the decomposition of the borated polyethylene compared to a virgin polyethylene sample and a generic polyethylene sample. 


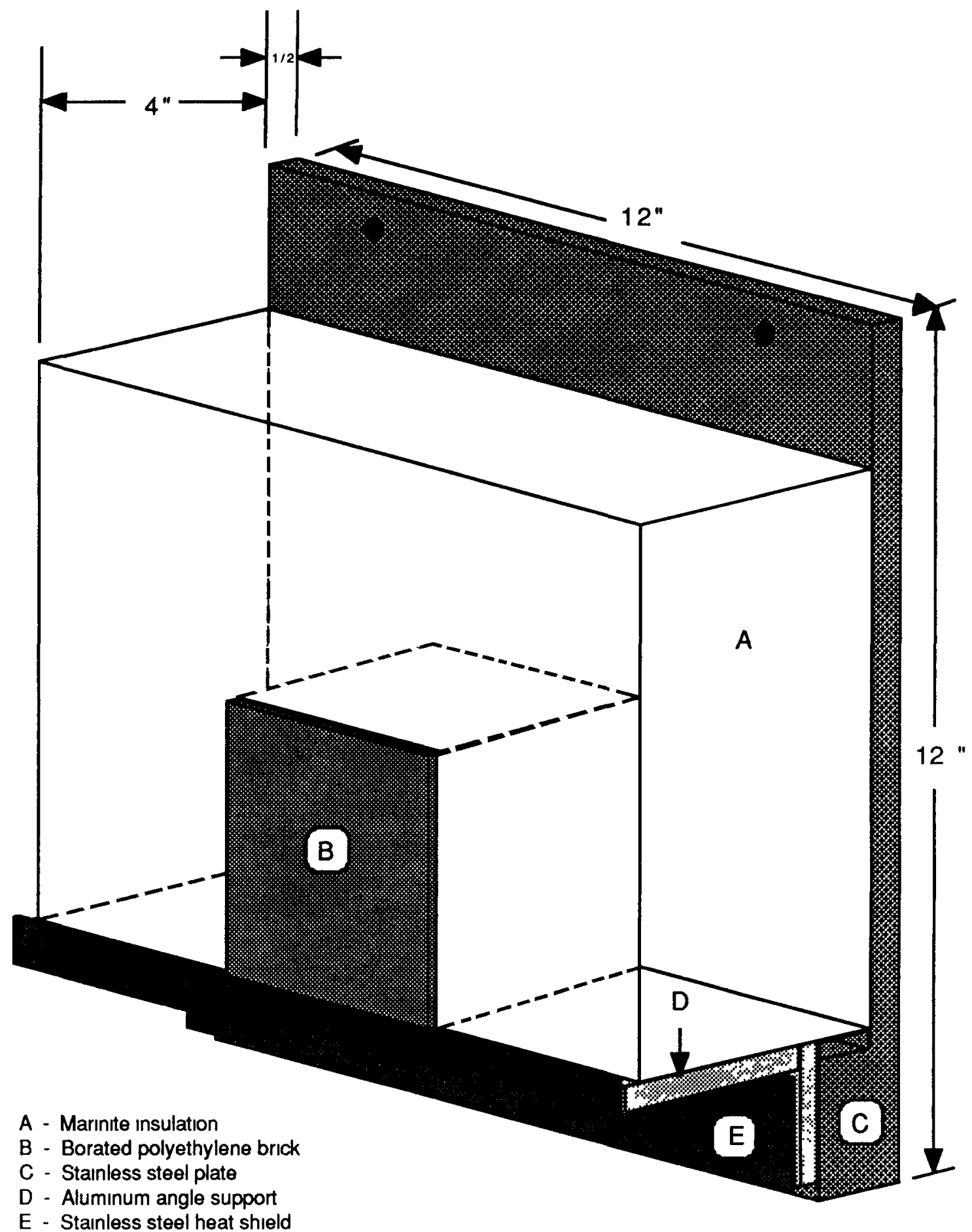

FIGURE 4 Schematic detall of the borated polyethylene test apparatus showing the view from the back of the apparatus away from the burner 


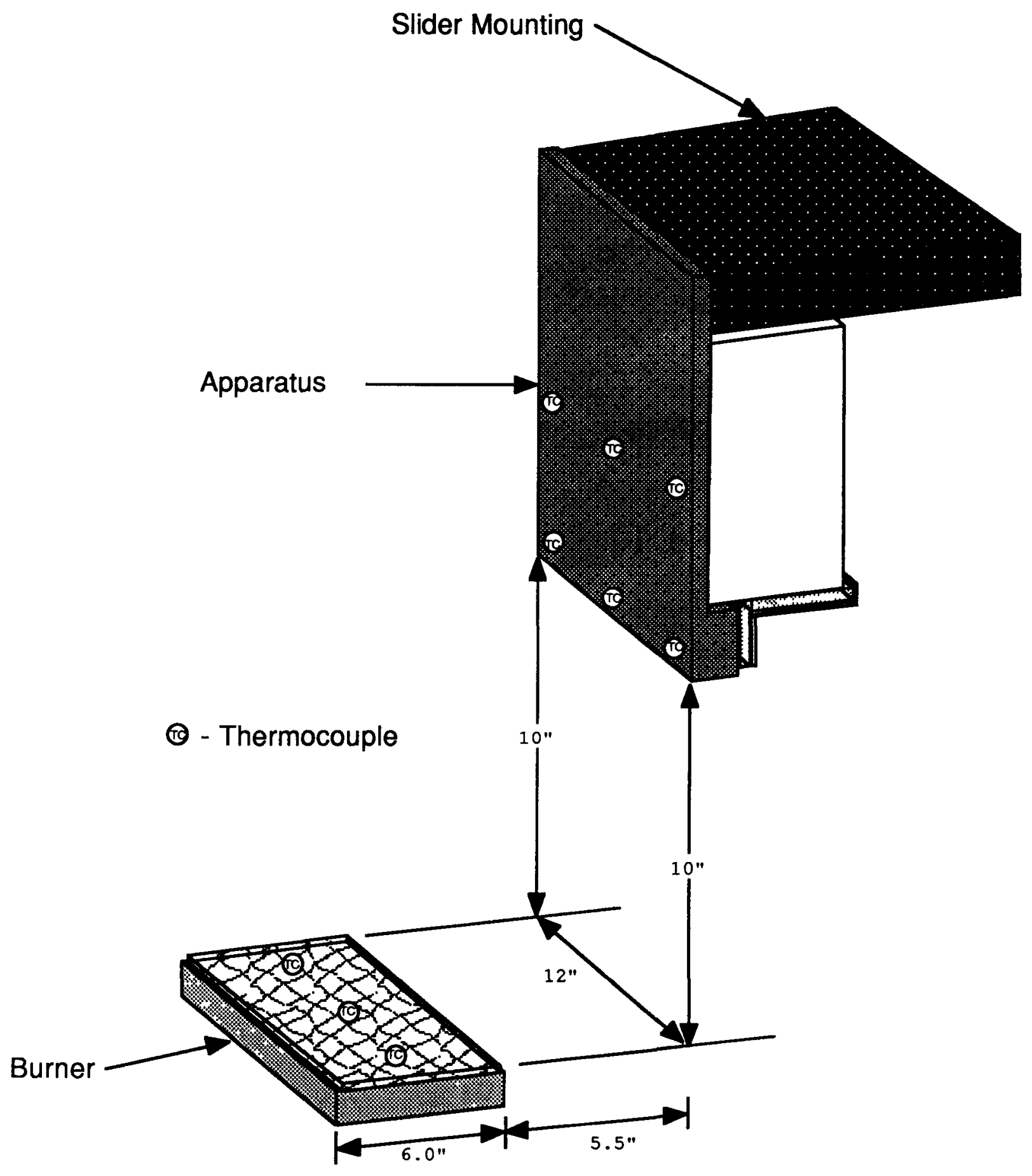

FIGURE 5. Schematic of the borated polyethylene apparatus showing the burner onentation and several thermocouple locations. 


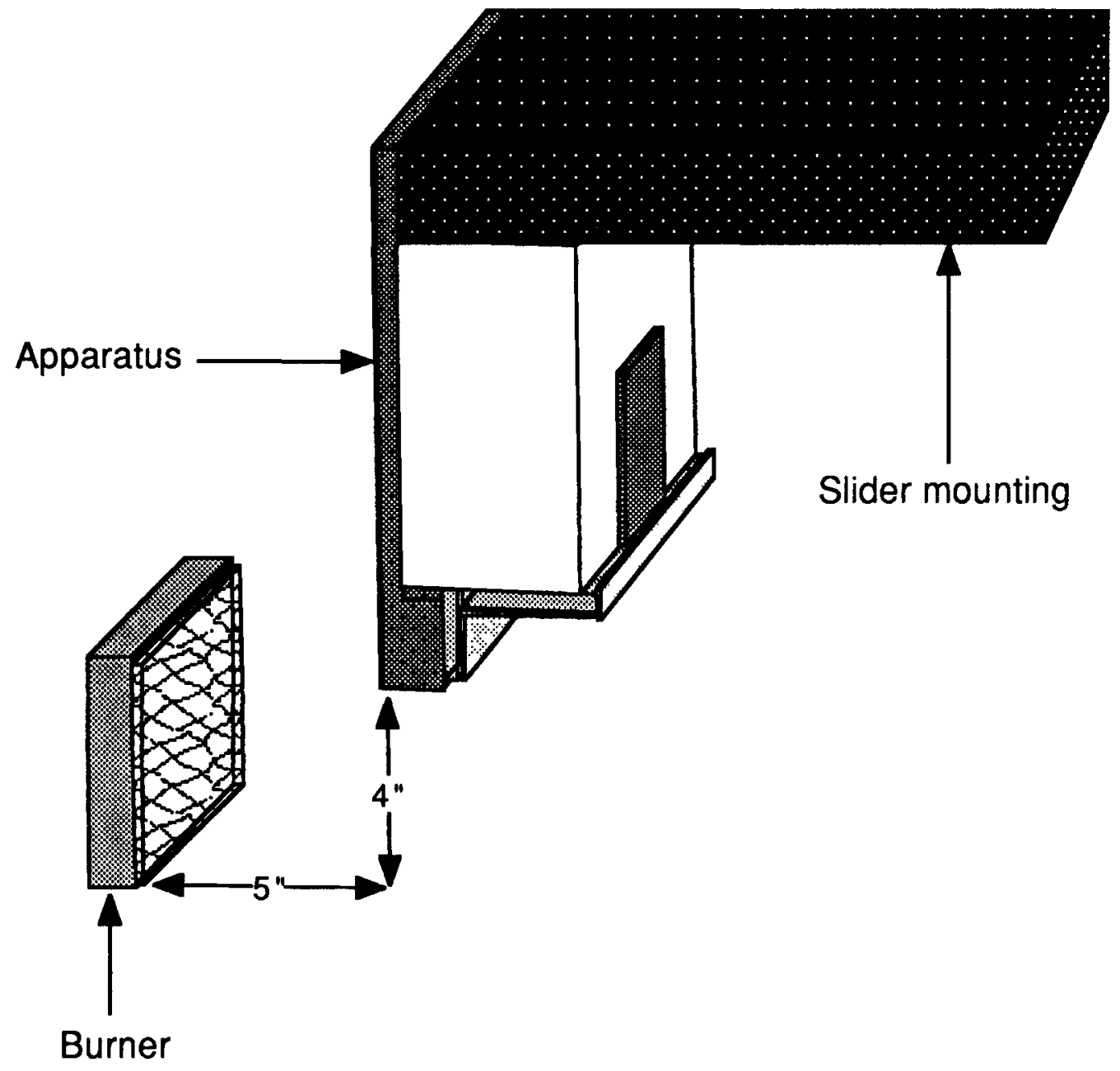

FIGURE 6. Schematic showing the burner in the vertical orientation in front of the borated polyethylene apparatus for Test 9. 


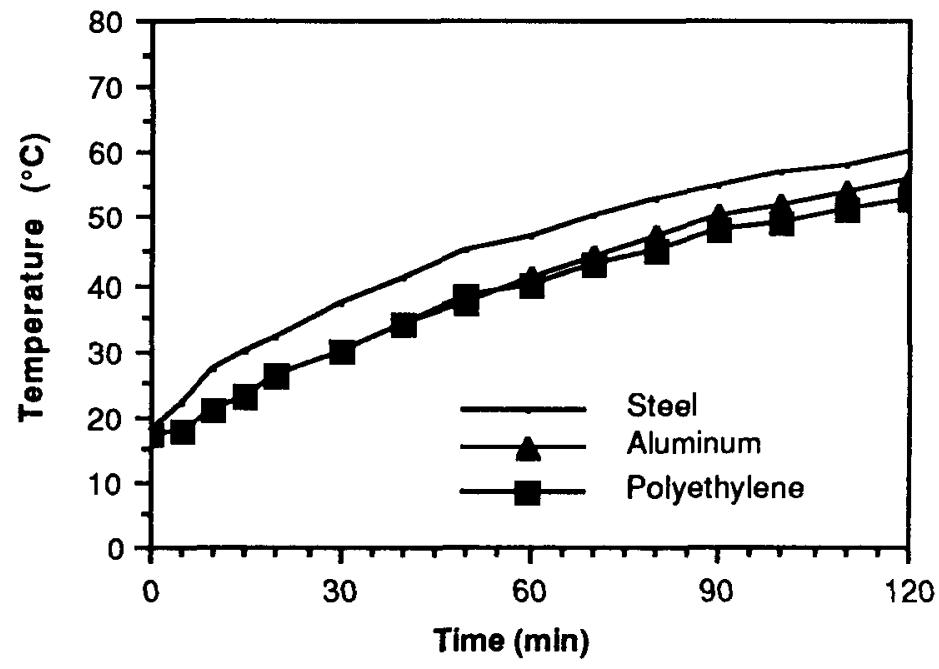

FIGURE 7. Plot of several thermocouples from Test 1 showing the temperature on the stainless steel face of the apparatus, in the aluminum angle and at the interface of the steel and the polyethylene 


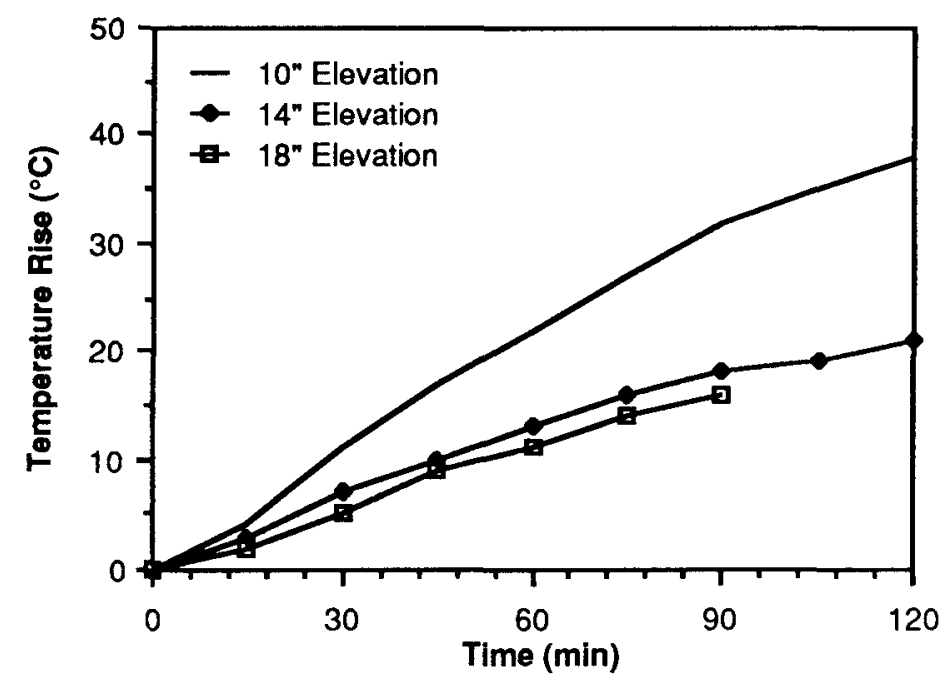

FIGURE 8. Plot of temperatures at the interface between the steel and the polyethylene for Tests 1-3 showing the effect of vertical position of the apparatus. 


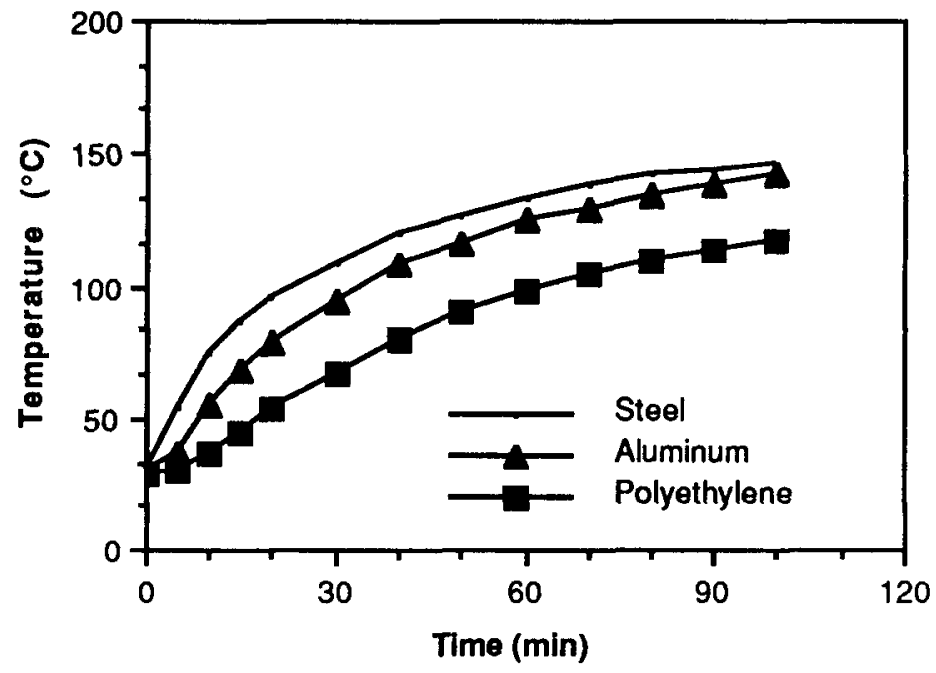

FIGURE 9. Plot of several thermocouples from Test 8 showing the temperature rise of the stainless-steel plate, the aluminum angle, and the borated polyethylene shielding material 


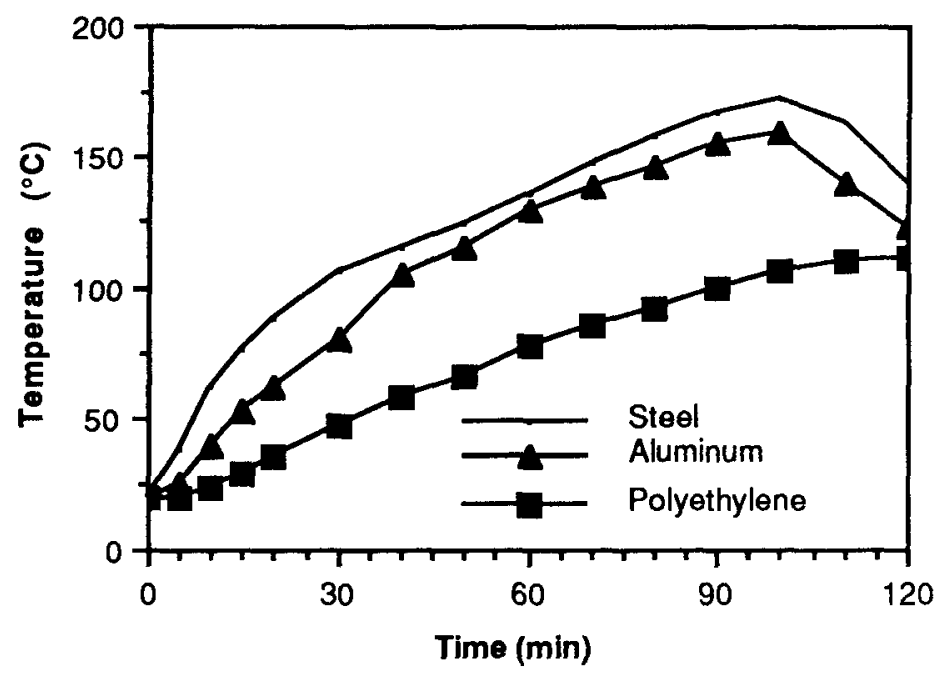

FIGURE 10. Plot of several thermocouples from Test 9 showing the temperature rise of the stainless steel plate, the aluminum angle, and the borated polyethylene shielding material. 